\title{
Science Explanations in News Coverage of the First Stem Cell Controversy
}

\author{
Kristen Alley Swain, University of Mississippi, USA \\ Jennifer Hutt Hobson, Freelance Writer, USA
}

\begin{abstract}
Science writing curricula often stress the importance of using explanations to make a story understandable to readers. This study examines the use of explanation in news coverage of the first stem cell controversy in the U.S., through a content analysis of 343 news stories appearing in three major newspapers, three national newsweekly magazines, and three national network television news websites from 1994 to 2001. Two-thirds of the explanations were simple definitions. Consistent with previous research, the use of explanation was highest in specialized science sections and did not vary according to story length. However, online sources had the highest proportion of stories with in-text explanation (excluding links to related materials), challenging the idea that science explanation usage is deadline dependent. Stem-cell stories that reflected more play, in terms of length and placement, did not include more scientific explanations. However, more scientific explanations did appear in science or health section stories about stem-cell research, regardless of story play. Traditional print newspapers and newsmagazines did not provide more scientific explanations in stem-cell stories than web sites for broadcast and cable networks.
\end{abstract}

Keywords: explanation, story play, science news, content analysis, stem-cell research 
This study examines the use of explanation in both online and print media coverage of stem cell research. Hailed by some as a major breakthrough in biomedicine (Okarma, 2001), human embryonic stem cell research has become one of the most controversial scientific developments in recent decades (Holland et al, 2001). Potential applications to a host of degenerative tissue and organ diseases led Time magazine to declare it a possible "miracle cure" (Lemonick, 1999). However, the medical promises of stem cell research come at a price that many believe is too high (Holland et al., 2001).

The religious and ethical implications of using human embryos for research has galvanized public opinion, spurring social as well as political debates and landing much media coverage (Holland et al., 2001). References to stem cell research since have appeared in political stories (Fuss, 1999), finance stories (Pollack, 2001), and editorials (Clark, 2001), in addition to frontpage news stories and science or medicine stories (Gillis \&Cannolly, 2001; Rowland, 2001).

\section{Background}

Stem cells, self-renewing cells that have not differentiated, are not committed to becoming one specific type of cell and may give rise to a variety of cells and tissues in the body (Holland et al., 2001). Stem cells also have the capacity for prolonged self-renewal and enable the body to regenerate tissues such as bone marrow. Researchers suggest stem cells cultured in a laboratory one day may be used to treat diabetes, arthritis and cancer, or to grow replacement tissues for spinal cord injuries or heart disease, making stem cells "perhaps the most extraordinary cells ever discovered" (Okarma, 2001).

Although stem cells have been obtained from adults, possibly the most promising research has involved human embryonic stem cells. Such research has also been the most controversial. Embryonic stem cells are derived by first destroying the outer shell of a blastocyst. Cells from the inner cell mass are then cultured for use in research. Because the procedure involves destroying embryos, religious groups and some bioethicists have objected (Holland et al., 2001).

Concerned citizens have followed and participated in the ensuing debate. In 1998, 
PresidentClinton established the National Bioethics Advisory Commission (Holland et al., 2001), and President Bush addressed the issue as well when he outlined strict conditions for federal funding of the controversial research in August 2001. Many researchers insist the study of embryonic stem cells is extremely important for medical science (Holland et al., 2001). Okarma (2001) notes the role public understanding and support plays in such research. "Like many new technologies, successful development and use of stem cells for human therapeutics will depend not only on their safety and efficacy, but also on their acceptability to society at large" (p. 11).

\section{Literature Review}

Rowan's (1988) theory of explanatory discourse defines explanatory writing as "discourse primarily designed to promote understanding by lay readers of some phenomenon" (p. 29). Some research supports the idea that explanatory writing may be linked to improved understanding of scientific and technical concepts (Myers et al., 1983), and professional science writers stress the use of explanation in their writing (Blum \& Knudson, 1997; Gastel, 1983). However, relatively little explanation appears in published science-related stories (Long et al., 1991, 1995).

Rowan (1988) asserts that explanatory discourse differs from informatory discourse primarily in terms of readers' perceived knowledge. While informatory text provides information about a topic that the writer assumes is already familiar to readers, explanations help readers understand those terms and ideas that are unfamiliar. Rowan describes three types of explanations: elucidating, quasi-scientific, and transformative. Quasi-scientific explanations promote understanding by helping readers assimilate information and understand a model process or procedure. Elucidating explanations help overcome difficulties with jargon by defining unfamiliar terms. Long and associates (1995) argue that transformative explanations aim to change a reader's understanding by rejecting and replacing misconceptions. This generally takes place on a story-wide scale and is often latent within the text.

In 1965, the U.S. House Subcommittee on Science, Research and Development asserted: "Any nation wishing to survive in the modern world ... must equip its citizenry with the knowledge and 
skills demanded by this scientific and technological age and with the understanding to cope with future technological developments" (Krieghbaum, 1967, p.6). In the U.S., the level of public knowledge in science -- sometimes called scientific literacy -- remains relatively low (Durant et al., 1989; Pellechia, 1997), even though public interest in general science and technology continues to grow (Durant et al., 1989; Atwater, 1988; Pellechia, 1997; Nunn, 1979). For example, one survey found that $92 \%$ of those questioned had a moderate to high interest in media stories about medicine, and 65\% had similar interest in science (Howard et al., 1987).

Although researchers argue about the best way to define and measure scientific literacy, most agree that a greater public knowledge and understanding of science is desirable (Miller, 1998; Burkett, 1965; Popli, 1999; Krieghbaum, 1967; Richards, 1996). Such knowledge is necessary if people are to think critically about the decisions they make regarding new technologies (Nelkin, 1995) or become involved in public debates about the future of scientific research (Richards, 1996). Despite the proliferation of university and government programs designed to promote public understanding of science, the mass media remain the primary source of new science knowledge among adults (Blum \& Knudson, 1997; Nelkin, 1995; Long, 1995; Burkett, 1965; Atwater, 1988; Rowan, 1990; Bader, 1990; Freedman et al., 1996; Krieghbaum, 1967). Even in classrooms, science sections of newspapers have been used to supplement traditional education (Krieghbaum, 1967). In 1995, Nelkin wrote: "For most people, the reality of science is what they read in the press. They understand science less through direct experience or past education, than through the filter of journalistic language and imagery" (p. 2).

Many journalism textbooks reflect an awareness of the role that science stories play as educational tools in American society (Burkett, 1986; Rowan, 1990; Stoval, 1998; Gastel, 1983). Inthe introduction to A Field Guide for Science Writers, Blum \& Knudson (1997) explain: "For the vast majority of Americans, newspapers are the sole source of information and continuing education about science... So science stories often must also be short courses in the scientific background needed to understand the news" (p.8). Blum \& Knudson suggest the use of explanations, rather than simple statements of fact, provide such background in stories about scientific subjects. 
Specifically, journalism texts caution against the use of jargon or undefined scientific terms. Burkett (1965) wrote: "One barrier to understanding and popularization is the language of science. This specialized language of precise technical terms laced with jargon is not spoken by laymen." Burkett's list of helpful tips for reporters covering science includes "translating stiff, technical jargon" and defining unusual or technical terms (p. 70).

Although some introductory journalism books also urge writers to avoid jargon and unfamiliar words altogether (i.e., Stovall, 1998), Gastel (1983) instructs those writing about science to use some science terms with sufficient explanation. Gastel points out that some technical terms, if explained, are of lasting use to readers and aid their understanding. This assertion is supported by research that found explanations significantly aid readers' understanding of technical information and the ability to apply what is learned (Myers et al., 1983).

Friedman et al. (1996), who studied newspaper coverage of Alar spraying on apples, asserted that the media has a responsibility to provide scientific explanations. It is clear that media coverage of scientific topics has, at least partially, an explanatory aim (Burkett, 1986; Blum \& Knudson, 1997; Nelkin, 1995; Rowan, 1990). Science writers, in particular, build their careers on the ability to explain or translate scientific knowledge (Burkett, 1986), and consider it their duty to make complex subjects clear enough for readers to understand (Blum \& Knudson, 1997).

Explanations are vital for providing context (Friedman et al., 1996; Pingree et al., 2000). However, journalists often have been criticized for writing science stories using a "bits-andpieces" approach. In general, newspapers neither include an explanation of the scientific methods used in the research study nor were the limitations of the study noted. As a result, the coverage tends to popularize science while presenting facts that lack context or basic information about the scientific research process (Pellechia, 1996).

Explanation is a key element of news framing (Parisi, 1999). The frames that journalists use in science stories can carry important implications for policy decisions and citizen participation in those decisions. For instance, zero-risk frames, which hold that any level of risk is unacceptable, 
tend to emerge when a controversy involves environmental or health risks (Kaufman \& Smith, 1997). Similarly, a complexity frame can lead stakeholders either to treat information with undue respect or to unduly discount it. For instance, a "science-as-truth" frame places faith in data and analyses, and implies that a conflict could be resolved if only sufficient scientific information were available. On the other hand, a "science-as-deception" frame labels scientific information as non-conclusive and untrustworthy because scientists, politicians, and consumers can manipulate it. This frame may lead the public facing complex science information to evaluate arguments in terms of their proponents and motives attributed to them, rather than the merits of the technical information (Gray \& Donnellon, 1989).

When people try to make sense of complex information, they often use frames to organize knowledge (Tannen, 1979), lighten the information-processing burden (Tversky \& Kahneman, 1991), and reduce the need to gather information and examine details. However, as the level of complexity rises, it becomes increasingly difficult to scrutinize how well frames match the specifics of a situation. The more complex the information is, the more likely an individual will make choices based on a sketchy interpretation of reality. According to Bartlett (1932), this often happens because an individual tends "simply to get a general impression of the whole and, on the basis of this, he constructs the probable detail" (p. 206).

Journalists and other individuals tend to seek confirmatory evidence for what they believe to be true, neglecting any contradictory information (Tversky, 1996). They often reach for frames when trying to understand new and complicated events (Tannen, 1979, Sheppard et al., 1994). An issue requiring extensive explanation, or a frame-less issue, usually does not elicit public opposition, whereas frames carrying a shared or collective meaning -- a widely held "package" of views -- often do (Kaufman \& Smith, 1999). On the other hand, media coverage implying that only experts are able to understand the issues can discourage public dialogue (Kaufman \& Smith, 1999).

In the interest of educating the public about complex topics, most seasoned journalists are sensitive to the need for good explanations (Rowan, 1990) and will even help one another 
develop clear explanations (Nelkin, 1995). Indeed, many journalists argue that the contemporary role of print is to offer analysis and explanation (Princeton Survey Research Associates, 1997). Yet, previous studies have found that the amount of explanation in science stories is generally quite low (Long et al., 1991; Long, 1995; Rowan, 1988). Rowan (1988) observed, "Despite the importance of explanatory writing in the mass media and in education, good explanations for lay readers are often hard to find."

Long (1995) observed that most science stories contain less than $10 \%$ of explanatory material. Similarly, another study found that explanatory frames -- revealing how something works, how it fits into a larger trend, or how it evolved to this point -- accounted for only $12 \%$ of 2,269 newspaper articles (Princeton Survey Research Associates, 1997). Even newspaper science section stories include relatively little explanation associated with scientific concepts. Long et al. (1991) found that $62 \%$ of these stories explained two or fewer concepts.

To explain the inclusion of explanations in some stories but not others, these researchers considered the impact of writer-based variables. The significance of individual author characteristics was suggested Rowan's (1990) study, in which composition students with more knowledge of a topic wrote better explanations of related scientific concepts than students with less knowledge did. This finding suggests a relationship between explanation quality and the author's level of knowledge and understanding. However, Long et al. $(1991,1995)$ found that differences in author knowledge did not affect whether an explanation was more or less likely to appear in the story (Long et al., 1991, 1995). Specifically, reporters with expertise in science writing included no more explanation in their stories than general news reporters with less expertise (Long et al., 1995).

In addition to these writer-based variables, researchers have also looked at production-based factors. For example, science articles that appear in special feature sections contain more explanation than science stories that appear in news sections (Long et al., 1995). This does not seem to be a function of feature sections' tendency toward longer stories, however, because the same study found that lengthy stories did not include more explanation than shorter stories. 
Long and associates (1995) proposed that the differences observed between feature sections and news sections result from a difference in purpose between the section types, with special science sections being viewed as more explanatory in nature. They also found a difference in the amount of explanation according to the amount of time a writer spent on the story, suggesting short deadlines as another obstacle to explanation. Another factor in the use of explanation is whether a story is triggered by the release of a poll or report. Princeton Survey Research Associates (1997) found that newspaper stories covering a released report typically are framed as an explanation of how things work (19\%), ongoing trends (24\%) or reality checks (17\%).Studies by Rowan and Long suggest several additional factors that may influence the inclusion of explanations in science-related stories, but many questions are still unanswered. For example, previous studies have focused exclusively on print media, which has traditionally dominated the reporting about developments in medicine and science (Howard et. al., 1987). This trend was evidenced by studies in the 1960s, which found magazines and newspapers to be the preferred sources of science news (Swinehart \& McLeod, 1960; Shaw \& VanNevel, 1967). However, in recent years the Web has become an increasingly common source of public information (Eveland \& Dunwoody, 1998), highlighting the need for research about the use of explanation in online publications.

Researchers have yet to explore the use of explanations in media coverage of the human embryonic stem cell debate and whether the amount of explanation appearing in such controversial science stories follows trends previously observed by Rowan (1990) and Long et. al. $(1990,1995)$. The present study examines the following research question and hypotheses:

- RQ: How did stem cell news coverage utilize scientific explanations?

- H1: Stem-cell stories that reflect more play (in terms of length and placement) will include morescientific explanations.

- H2: Morescientific explanations will appear in science or health section stories about stem-cell research, regardless of story play.

- H3: Traditional print newspapers and newsmagazines will provide more scientific explanations in stem-cell stories than web sites for broadcast and cable networks. 


\section{Method}

Content analysis is a useful technique in analyzing trends and changes in content over time and in examining changes in media coverage of science (Ogles, 1985). This study is a content analysis of 343 articles about stem cell research that appeared in three U.S. elite newspapers, three national U.S. newsweekly magazines, and on three U.S. broadcast/cable network websites appearing between 1994 and 2001. The sampling frame included coverage from three newspapers, New York Times, Los Angeles Times and Washington Post, chosen for their elite status and their agenda-setting abilities. The newsweeklies Newsweek, Time and U.S. News and World Report were included for the same reason. Broadcast and cable networks have begun generating original copy for their online sites (About Us, 2002). To include this new media, articles were selected from the cable network CNN.com, and broadcast networks MSNBC.com and CBS.com. A third broadcast network, ABC, also posts copy on its web site. However, ABC.com was excluded from this study because it does not allow full access to archived web site articles.

Articles published from January 1994 to September 30, 2001 were included in the sample. This date range included both the earliest stories to specifically discuss human stem cells and the most recent articles available at the time of the study, including stories that followed President George W. Bush's August 2001 announcement regarding federal funding limitations for continued stem cell research. The rationale for choosing the beginning point as 1994 was that a Lexis-Nexis search dating back to 1979 showed 1994 to be the first year that any major U.S. newspaper provided coverage of human embryonic stem cells. While scientists have known for 35 years that cells found in bone marrow can form different tissues (Friedenstein et al., 1966), it was not until 1992 that researchers were able to isolate this cell population from human tissue (Haynesworth et al., 1992). The chosen ending date was September 30, 2001 because this was the last day of the third quarter of 2001 and the most recent coverage available at the time of the study. The time frame included coverage of the report issued Sept. 11, 2001 by the National Academy of Sciences that advocated public funding of stem cell research (NAS, 2001). 
The search terms "stem cell" and "research" were used to conduct Boolean searches of the Lexis-Nexis Academic Universe database, the Time magazine searchable online archive, and searchable online archives for the three network websites. The term "stem cell" was not used as a keyword alone because it resulted in too many articles unrelated to stem cell issues. Using the keyword "stem cell" AND "research" eliminated most undesirable articles. The total number of hits constituted a universe of 1,860 articles, and the majority of these articles appeared in the newspapers or on the websites. To ensure a sufficient sample, a systematic sample of articles was selected from each publication. Beginning with a random article in the list of returns, the researchers selected every third article from each web site, every seventh article from each newspaper, and the first two of every three articles in the newsweeklies. Only articles containing information about the application of stem cell research on humans were considered. An article was excluded from the sample if it did not mention stem cells specifically somewhere in the story, if the story length was less than 100 words, or if it was an advertisement or obituary. These guidelines were established to ensure that articles sampled for the study were relevant to stem cells and contained either news or editorial content on the subject. The length requirement filtered out extremely short news briefs and announcements.

In a pilot study of 40 articles from the nine publications and other materials about human stem cell issues, qualitative analysis revealed possible exploratory research questions, search terms, variables, variable categories, and other coding parameters. The final code sheet included 31 variables, including publication, section type, article length, definition type and explanation length. Additional variables coded for use in a related study are not discussed here. For the present study, the following variables were coded:

- Scientific explanation: Consistent with previous research (Long, 1995), this study focused on media usage of scientific definitions and explanations by recording use of quasi-scientific and elucidating explanations of terms, processes and procedures. Elucidating explanations are those that define or clarify a certain difficult term or phrase in order to help readers understand its meaning and usage (Rowan, 1988, 1990). For example, an elucidating explanation of stem cells from CNN.com reads, "Stem cells are blank cells that can be turned into specialized cells such as heart cells, or any kind of tissue in the body, such as skin, 
muscle or the brain" (Blood Cells, 2001). Quasi-scientific explanations help readers "model or mentally represent some aspect of reality" (Rowan, 1990, p. 26). An example might be an explanation of how a particular process works, the relationships involved, or how the different steps of a procedure come together for the completion of a task. Any definition, scientific process, or scientific background information about stem cells was coded under the scientific explanationvariable. The name of the term or process was coded, along with a word count. Coders recorded both the topic and length of each elucidating or quasi-scientific explanation provided within the text of an article. Explanation length was measured by word count, and each explanation was coded as less than 10 words, 10-25 words, or more than 25 words. For the websites, only in-text explanations were coded, excluding material contained in hyperlinked pages, glossary boxes, etc. This rationale was based on previous research (i.e., Eveland\& Dunwoody, 1998) indicating that most viewers skip or ignore out-of-text, non-linear options on media websites. If an article contained an explanation not related to stem cells, the information was not coded. Any explanation that only consisted of a list of diseases or health issues was not counted as a definition.

- Date: The month, day, and year were determined by the story header and were recoded into months and quarters for each year of the time frame. Although some articles from MSNBC, $\mathrm{CNN}$, and CBS contained the month and day but not the year of publication, the year always could be determined from the article's content.

- Length was recorded as the numerical word count of the article, which Lexis-Nexis provided in the story headers. For the website articles and Time articles, the length was determined by pasting the article text into Microsoft Word and then running the word count function. The length was recorded on the code sheet as both the raw count and as one of 11 length categories.

- Story focus was determined by examining the headline and first three paragraphs. The focus was coded as either "stem cell related" or "not stem cell related."

- A play variable, developed as a measure of newsworthiness for newspaper coverage, combined story placement (as indicated by section letter and page number) and story length (word count category). The play variable consisted of eight categories, ranked from highest to lowest play: (1) front page, length $\geq 1,000$ words; (2) front page $<1,000$; (3) front/first 
section interior $\geq 1,000$; (4) first section interior $<1,000$; (5) section cover $\geq 1,000$; (6) section cover <1,000; (7) interior (not 1st sect) $\geq 1,000$; and (8) interior (not 1st sect) $<1,000$ words.

Four coders analyzed the final sample, which consisted of 124 website articles, 157 newspaper articles and 62 articles from newsweeklies, for a total of 343 articles. After the coding, all "other" category variables were recoded into new categories. Code sheet data was analyzed using SPSS statistical software. Twenty percent of the sampled articles were double-coded, revealing an overall intercoder reliability of $95 \%$. Intercoder reliability coefficients for specific variables were $97 \%$ for the explanation category, $84 \%$ for explanation length, $87 \%$ for section type, $98 \%$ for play, $100 \%$ for length, $100 \%$ for year, and $100 \%$ for publication code.

\section{Results}

The research question examined how stem cell news coverage utilized scientific explanations.Of the 343 stem-cell stories in the sample, 39\% contained at least one scientific explanation or definition, while $61 \%$ included no explanations. Overall,63\% of the stories appeared after President Bush took office in 2001. Prior to 2001, 19\% of the stories contained short explanations fewer than 10 words in length, 44\% contained medium-length explanations (10-25 words), and $37 \%$ contained the longest explanations (more than 25 words). Although the coverage spiked after Bush took office, the previous explanation pattern continued to hold. In $2001,17 \%$ of the stories contained short explanations, $48 \%$ used medium-length explanations, and $34 \%$ contained long explanations.

H1, which posited that stem-cell stories reflecting more play (in terms of length and placement) will include more scientific explanations, was not supported (see Tables 1, 2, and 3). Of the coded stories, $88 \%$ were $100-1,500$ words long. Although a smaller percentage of stories 300 words or fewer contained explanation (19\%) than most other categories, there was no clear trend to indicate longer stories are more or less likely to include explanation. Almost half the stories that were 301-500 and 501-700 words in length contained explanation (46\% each). Lower percentages of articles 701-900 or 901-1,100 words long contained scientific explanation (37\% and $41 \%$, respectively). However, stories 1,101-1,300 words long were more likely to include 
explanation (57\%) than others. The lowest percentages of explanatory articles appeared in the 1,301-1,501 word category (23\%), 1,501-1,700 word category (11\%), 1,701-1,900 word category (25\%), and the 1,901-2,000 word category (none). Yet, the highest percentage of stories with explanations was in stories with more than 2,100 words (64\%).

For all three media, the most frequent length of a scientific explanation and/or background statement was 10-25 words; 94 stories (27\%) contained an explanation in this length category. Explanations fewer than 10 words in length appeared in 37 stories (11\%) of the total sample, and those more than 25 words long appeared in 70 stories (20\%). These stories combined to constitute the 135 explaining articles coded in the study, with some overlap as explanations of varying length appeared in the same story. The website articles contained the longest $(>25$ words) scientific explanation and/or background material (31\% of website articles). The shortest scientific explanation and/or background material category ( $<10$ words) accounted for $30 \%$ of the newsmagazine articles.

There was an inverse relationship between story length and frequency of explanations. Shorter stories were significantly more likely to contain explanations than longer stories $(r=-0.82$, p $>0.05$ ). However, $73 \%$ of the longest stories (greater than 2,100 words)used long explanations of 25 words or more. The longest stories also had more short explanations (55\%), relying more heavily on short explanations than long ones.

$\mathrm{H} 2$, which asserted that more scientific explanations will appear newspaper stories in science or health sections, regardless of story play, was supported.Across newspapers, the number of explanations per story was consistent across story play categories and length categories. Most explanations ran in an interior section other than the front section (55\%), followed by interior front section (32\%), the front page (10\%), and section covers (3\%). Most of the shortest explanations (less than 10 words) appeared in an interior non-front section (63\%), followed by the front section interior (25\%), and on the front page (13\%). For the explanation length category accounting for the most coverage (10-25 words), 59\% of the explanations appeared in a non-front interior section. 
Among the newspapers, $77 \%$ of all stories appeared in one of six section types: local/state (22\%), opinion/editorial (18\%), health/medicine (13\%), top/U.S. (12\%), science/technology (6\%), political (6\%), and international/world (2\%). The remaining stories either listed no section type $(11 \%)$ or appeared in less common sections such as finance (3\%), law $(0.3 \%)$, or entertainment $(0.3 \%)$. Although most stem-cell stories appeared in non-science/health sections, across the six leading section types, the health section had the highest proportion of stories with explanations, at $72 \%$, twice as high as any non-science/health section. Science and technology sections included explanations in $42 \%$ of the stories. This was followed by $36 \%$ of state and local news stories and less than $25 \%$ of national or international news, political stories or editorials.

Explanations were grouped into the following categories for analysis: stem cells, stem cell lines, differentiation, cloning, embryo/blastocyst, diseases, and scientific processes or procedures. The category "stem cells" included general definitions for stem cells as well as specific definitions for embryonic stem cells and various organ-specific stem cells. A total of 190 explanations appeared in the 135 explaining stories. Of these explanations, $63.7 \%$ defined stem cells or a specific type of stem cell. Scientific processes and procedures constituted $11 \%$ of the explanations, with most other explanation categories at $4-5 \%$ each.

$\mathrm{H} 3$, which predicted that traditional print newspapers and newsmagazines will provide more scientific explanations in stem-cell stories than web sites for broadcast and cable networks, was not supported (Table 4). The broadcast news websites consistently provided more science explanations/definitions across the six explanation categories, twice as many as the newspapers and three times as many as the newsmagazines did. The explanationtype used most frequently was "scientific processes" (9\% of all stories), followed by cloning (6\%), stem cell lines (5\%), disease (4\%), embryo/blastocyst (3\%) and differentiation (1\%).

Online broadcast stories were more likely to include explanations than print stories, with $57 \%$ of web stories including at least one explanation compared with only $28 \%$ of newspaper stories and $48 \%$ of newsweeklies. The broadcast websites also defined stem cells most frequently, in $56 \%$ 
of these stories, as compared with $20 \%$ of newspaper stories and $34 \%$ of newsweekly stories. CBS was the most likely to provide stem cell definitions (in $80 \%$ of its stories), followed by MSNBC (61\%) and Time magazine (47\% of its stories). Among the broadcast websites, CBS had the most stories containing explanations (70\%), followed by MSNBC (56\%) and CNN (44\%). Among the print publications,Timemagazine had the highest number of stories containing explanations (77\%), followed by Newsweek (39\%), Los Angeles Times (34\%) and Washington Post (34\%). The New York Times was the least likely of the publications to use explanations (just $17 \%$ of its stem-cell stories) and the least likely to define stem cells, even though all its explanations were stem-cell definitions.

\section{Discussion}

Despite the complexities surrounding stem cell research and its pervasiveness in the news media, the use of scientific definitions and other explanations has been relatively low. Greater than half of the stories contained no explicit explanation whatsoever, and those that did often limited their explanations to less than 25 words. Across most publications, section types and story lengths, the medium-length explanations were most common, followed by longest, then shortest explanations.

This study focused on media use of scientific definitions and explanations, as described by Rowan's (1988) theory of explanatory discourse. The study found that $67 \%$ of the explanations were definitions, elucidating explanations that clarified a certain difficult term or phrase to help readers understand its meaning and usage. The other third of the explanations were quasiscientific, designed to help readers "model or mentally represent some aspect of reality" (Rowan, 1990), such as processes or procedures.

Consistent with the observations of Long et al. (1995), the present study found that stories appearing in specialized science or feature sections are more likely to contain explanatory discourse than those appearing elsewhere. Specific factors contributing to this pattern are somewhat elusive. Space considerations do not appear to be a significant factor, as this study supported previous findings that story length is not related to explanation use. However, in light 
of Rowan's theory of explanatory discourse that classifies explanatory text based on its aim, a writer's decision to include explanatory passages might partly depend on the perceived goal of both the article and the publication in which it appears. For instance, the science section may be intended to be more educational in purpose than other sections.

The journalists' tendency to neglect use of explanation also could be deadline driven, as supported by findings where writers provided more explanation when given more time to complete a story (Long et al., 1995). This would seem to explain, at least partially, the difference between special feature sections and news sections, since feature sections usually publish less frequently. Weekly newsmagazines also used more explanation than daily newspapers. However, the online television websites used explanations more often than newspapers or newsmagazines, even though these sites typically post new stories several times throughout each day (About Us, 2002). The relatively high proportion of explaining stories in online media coverage casts doubt on the idea that deadlines play a large role in the decision to include explanations within a science-related story. It is more likely that the inclusion of explanations is a matter of purpose, as also suggested by Long (1995).

Reporting about controversial scientific topics presents unique challenges, particularly in providing definitions and explanations of scientific concepts (Friedman et al., 1996; Miller, 1998). The broadcast websites appeared to be the best medium for providing explanatory material, while newsmagazines appeared to be the least effective in this regard. Broadcast websites also provided longer in-text scientific explanation and background material than the newspapers did.

Special feature sections for stem cell coverage may be viewed as supplementary to the news and more explanatory in nature. Similarly, producers of web-based media may see their product as a secondary news source and, as such, more explanatory in purpose. Future studies could explore whether journalists or readers perceive some media as more explanatory in purpose than others. Identifying the factors that influence explanation in a story may equip reporters to explain more often and more thoroughly. In the meantime, both the amount of explanation in science stories 
and public understanding of science remain relatively low. 


\section{References}

Atwater, T. (1988).Reader interest in environmental news.Newspaper Research Journal, 10 (1), 31-39.

Bader, R. G. (1990). How science news sections influence newspaper science coverage: A case study. Journalism Quarterly, 67 (1), 88-96.

Bartlett, F. C. (1932). Remembering: A Study in Experimental and Social Psychology. Cambridge, UK: Cambridge University Press.

Blum, D. \& Knudson, M. (1997).A Field Guide for Science Writers. New York: Oxford University Press.

Burkett, D. W. (1965). Writing Science News for the Mass Media. Houston: Gulf Publishing Co.

Burkett, W. (1986).News Reporting: Science, Medicine, and High Technology. Ames, Iowa: Iowa State Press.

Carver, T. G. (1968). Editorial attitudes toward health insurance legislation.Journalism Quarterly, 45 (1), 129-30.

Clark, J. (2001). Squandering Our Technological Future.New York Times, p. A19.

Durant, J. R., Evans, G. A., \& Thomas, G. P. (1989).The public understanding of science.Nature, 340 (6228), 11-14.

Eveland, W. P., \& Dunwoody, S. (1998). Users and navigation patterns of a science World Wide Web site for the public.Public Understanding of Science, 7 (4), 285-311.

Friedenstein, A. J., Piatetzky, S., \&Petrakova, K. V. (1966). Osteogenesis in transplants of bone marrow cells.Journal of Embryology and Experimental Morphology, 16 (3), 381-387.

Friedman, S. M., Villamil, K., Suriano, R. A., \&Egolf, B. P. (1996). Alar and apples: Newspapers, risk and media responsibility. Public Understanding of Science, 5, 1-20.

Fuss, B. (1999). Michael J. Fox Seeks Health \$\$. CBS News.http://www.cbsnews.com/stories/1999/09/28/politics/main64092.shtml.

Gastel, B. (1983). Presenting Science to the Public. Philadelphia: ISI Press.

Gillis, J., \&Cannolly, C. (2001). Stem Cell Research Faces FDA Hurdle: With Mouse Cell Base, Tough Rules Apply. Washington Post, p. A1. 
Gray, B., \&Donnellon, A. (1989).An Interactive Theory of Reframing in Negotiation.Unpublished manuscript.Pennsylvania State University, College of Business Administration.

Holland, S., Lebacqz, K., \&Zoloth, L. (2001).The Human Embryonic Stem Cell Debate: Science, Ethics, and Public Policy. Cambridge, MA: MIT Press.

Howard, H. H., Blick, E., \& Quarles, J. P. (1987).Media choices for specialized news.Journalism Quarterly, 64 (2), 620-623.

Kaufman, S., \& Smith, J. (1997). Implementing change in existing locally unwanted land uses: A case study. Journal of Planning Education and Research, 16 (3), 188-200.

Kaufman, S., \& Smith, J. (1999). Framing and reframing in land use change conflicts. Journal of Architectural \& Planning Research, 16 (2), 164-180.

Krieghbaum, H. (1967). Science and the Mass Media. New York: New York University Press.

Long, M. (1995). Scientific explanation in U.S. newspaper science stories.Public Understanding of Science, 4, 119-130.

Long, M., Steinke, J., Kalter, J., Schwaab, A., Savagian, A., Jaffer, N, Shim, J., \& Wenzel, W. (1991). Explanation in newspaper science section news articles.Association for Education in Journalism and Mass Communication annual conference, Boston.

Miller, J. D. (1998). The measurement of civic scientific literacy.Public Understanding of Science, 7 (3), 203-223.

Myers, J. L., Hansen, R. S., Robson, R. C., \& McCann, J. (1983).The role of explanation in learning elementary probability.Journal of Educational Psychology, 75 (3), 374-381.

NAS (2001).Under the Microscope: Looking at Stem Cell Research. Washington, DC: National Academy of Sciences.

Nelkin, D. (1995). Selling Science: How the Press Covers Science and Technology. New York: W. H. Freeman \& Co.

Nunn, C. Z. (1979). Readership and coverage of science and technology in newspapers.Journalism Quarterly, 56 (1), 27-30.

Ogles, R. M. (1985).An Overview of Content Analysis for Communication Research.Unpublished manuscript.

Okarma, T. B. (2001). Human Embryonic Stem Cells: A Primer on the Technology and Its 
Medical Applications. In S. Holland, K. Lebacqz, \& L. Zoloth (Eds.), The Human Embryonic Stem Cell Debate: Science, Ethics, and Public Policy. Cambridge, MA: MIT Press.

Parisi, P. (1999). Astonishment and understanding: On the problem of explanation in journalism. New Jersey Journal of Communication, 7 (1), 44-64.

Pellechia, M. G. (1997). Trends in science coverage: A content analysis of three U.S. newspapers. Public Understanding of Science, 6 (1), 49-68.

Pingree, S., Hawkins, R., Yun, G. W., Park, S. Y., \&Serlin, R. (2000).Consumers' Use of Science Content and Site Address to Evaluate Web Health Stories.Association for Education in Journalism and Mass Communication annual conference.

Pollack, A. (2001, August 28). Obscure biotech company becomes big player in stem cell world. New York Times, p. C1.

Popli, R. (1999). Scientific literacy for all citizens: Different concepts and contents. Public Understanding of Science, 8 (2), 123-137.

Princeton Survey Research Associates (1997).Framing the News: The Triggers, Frames, and Messages in Newspaper Coverage: http://www.journalism.org/framing.html. Washington, DC: Project for Excellence in Journalism.

Richards, M. (1996). Lay knowledge of genetics and inheritance. Public Understanding of Science, 5 (3), 217-230.

Rowan, K. E. (1988).A contemporary theory of explanatory writing.Written Communication, 5 (1), 23-56.

Rowan, K. E. (1990).Strategies for explaining complex science news.Journalism Educator, 45 (2), 25-31.

Rowland, R. (2001, May 29). Skeletal stem cells may save ailing hearts. CNN: http://www.cnn.com/2001/HEALTH/conditions/05/29/heart.stem.cells/index.html

Shaw, D. L., \&VanNevel, P. (1967). Informative value of medical science news.Journalism Quarterly, 44, 548.

Sheppard, B. H., Blumenfeld-Jones, K., Minton, J. W., \&Hyder, E. (1994). Informal conflict intervention: Advice and dissent. Employee Responsibilities and Rights Journal, 7 (1), 53. 
Stovall, J. G. (1998). Writing for the Mass Media. Boston: Allyn \& Bacon.

Swinehart, J. W., \& McLeod, J. M. (1960). News about science: Channels, audiences and effects. Public Opinion Quarterly, 24, 583-589.

Tannen, D. (1979). What's in a frame? Surface evidence for underlying expectations.In R. O. Freedle (Ed.), New Directions in Discourse Processing. Norwood, NJ: Ablex Publishing, pp. 137-181.

Tversky, A. (1996). Contrasting rational and psychological principles of choice. In R. J. Zeckhauser, R. L. Keeney \& J. K. Sebenius (Eds.), Wise Choices: Decisions, Games, and Negotiations. Boston: Harvard Business School Press, pp. 5-21.

Tversky, A., \&Kahneman, D. (1991). Loss aversion in riskless choice: A reference-dependent model. Quarterly Journal of Economics, p. 1039-1061. 